\title{
Application and Practice of Information Technology under the Project Management of College Students' Innovative and Entrepreneurial Training Program
}

\author{
(PRESENTED)
}

\author{
ZHANG Liucheng \\ The practice teaching management center \\ Harbin University of Commerce \\ Harbin,China \\ zhangliucheng@126.com
}

\author{
ZHANG Li \\ The practice teaching management center \\ Harbin University of Commerce \\ Harbin,China \\ zhangli007008@126.com
}

\begin{abstract}
With the most extensive coverage and as the most influential project ,College Students' Innovative and Entrepreneurial Training Program belonging to Teaching Quality and Reform Project of Undergraduate Teaching in Colleges and Universities ,the project is aimed at cultivating college students' entrepreneurial quality and innovative spirit.The paper covers the research on the application of Information System to the Training Program .The paper mainly refers to the structure and function of intelligent management system of Innovative and Entrepreneurial Training Program .Besides, it also touches on the application ,the informatization management in the project review ,management of project process ,information management of assistance, monitoring and supervision on project research as well as informatization management of project funds .At the end of the paper ,the article concludes effects of Informatization Management on the College Students' Innovative and Entrepreneurial Training Program in Harbin University of Commerce, and make a positive attempted research on the innovation of the the management style and means of the College Students' Innovative and Entrepreneurial Training Program in Provincial Collegesand Universities .
\end{abstract}

Keywords-information technology ; innovation and entrepreneurship; application research

Ministry of Education has implemented college students' innovative and entrepreneurial training program since 2007, which will subsidize students in colleges and universities to develop some practical activities, including research learning and innovative experiment, design of entrepreneurial program, practical research of corporate operation, simulation of corporate operation and real entrepreneurship[1]. Since implementation of the project, more than 250,000 college students in colleges and universities around China have participated in it, which involves in twelve subjects, such as science, engineering, agriculture, literature and law, and thus becomes the most widely coverage and biggest influence item in the undergraduate teaching quality and teaching reform project[2]. In 2012, selected by the Ministry of Education, Harbin University of Commerce became one of the first batch of colleges and universities in Heilongjiang province

Fund Project: National-level Project of College Student's Innovative and Entrepreneurial T raining Program,Code of Project: 201410240011 implementing the project of national college students' innovative and entrepreneurial training program.

\section{RAISE THE QUESTION}

Harbin University of Commerce (abbr: HUC) has got 89 national-level projects, 61 provincial-level projects and 362 school-level projects since 2012. Through operation and management of these projects, the problems we have discovered involves in many aspects. For instance, it is not easy to have a choice because applied project and people cover a wide range and quality of project is also rather spotty. It is also difficult for us to invite some advisers, and coordination work is not simple[3]. Within the confinement of time and space, communication between teacher and student is limited. We have very little control over establishment, verification, defense of project and its fairness. We also difficultly take control of schedule so that we cannot accomplish the project on time. It is wide coverage area and large number that make summary statistics difficult[4]..Especially, storing the paper materials in a long period has not been done easily, which is not beneficial to refer and check. And how to manage research project fund and how to control effectively time arrangement are not simple problems to resolve on account of long-time span and complex procedure[5].

Serving for student and instructor is our duty of project management department. Through effective management, every valuable and meaningful project will be done smoothly, which makes students have the opportunity to participate in it, stimulates student's innovative thinking and awareness, develops student's entrepreneurial skill, creates innovative culture and thus improves the teaching quality. In order to solve the problems mentioned above and meet the require ment of innovative and entrepreneurial training program, we began to explore management method and process management mechanism, design and develop intelligent management system of innovative and entrepreneurial training program at Harbin University of Commerce in 2012, which has been put into usage and operation since 2013. 


\section{STRUCT URE AND FUNCTION OF INTELLIGENT MANAGEMENT} SYSTEM

Functions of management system runs through the entire process of college students' innovative and entrepreneurial training program, including project application, project review, project release, project contact, progress report, mid-term report, concluding report, result tracking, funds management, mutual communication between instructor and student and expert review. It is automatically collecting and statistical query of data that can monitor the project process, which has truly realized paperless office, network and informatization in the process of project management.

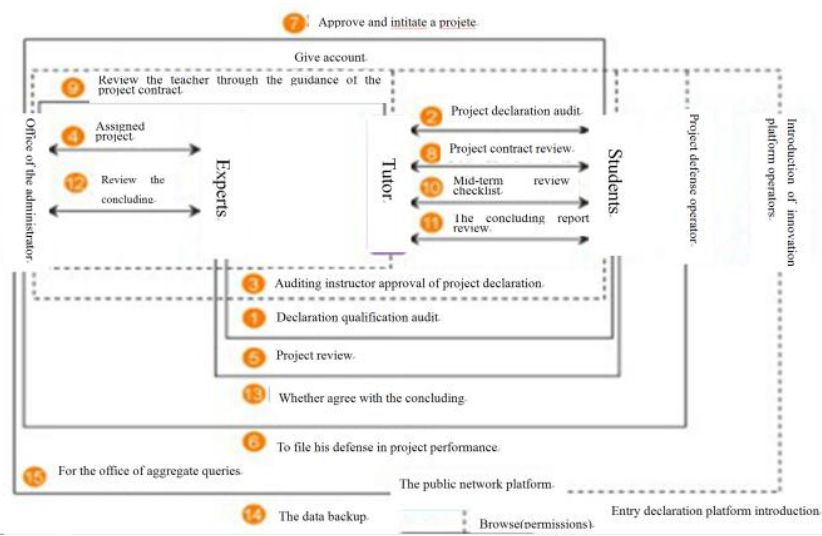

Fig. 1. Structure and Function of Intelligent Management System

\section{A. Informatization Management of Project Application and} Review

\section{1) Project Application Management}

a) Send Project Application Notice Timely and Accurately

In accordance with government documents from Ministry of Education and Provincial Educational Department, drawing up and sending the notice timely and accurately to the related department and people will stimulate teacher and student's enthusiasm. Wide publicity with a class as a group will also make preparations for project application and choice. On the other hand, we will post this piece of information in the first place on the school website for teacher and student to consult.

\section{b) Application Management of $3+2$ Program}

Project Project application at HUC has to go through college, university, province and more according to related regulation of HUC, namely, on the bases of student's collegelevel project applications, colleges will invite some experts from their own college to review these projects and then recommend them to university; they will be evaluated by experts from the University and recommended again as provincial or national scientific research project. These recommended projects will be optimally managed by center of practical teaching management and colleges in comb ination of some practical links, such as opening laboratory, student's competition and bachelor's degree thesis. Optimization of application process and paperless office are attributed to intelligent management system of innovative and entrepreneurial train ing program, by which students can fill in the material of project application and experts from colleges and university can finish project evaluation.

\section{2) Management of Project Review}

The process of project review covers student's online application, initial college evaluation, anonymous review from the university and public review from the university defense meeting to choose high-quality project by following the principle of openness, fairness and impartiality. With regard to the criteria for evaluation, we main ly focus on key disciplines, brand majors, characteristic and strategic majors and then cover gradually the other disciplines and majors. By taking some measures, the opportunity to study in these projects can be taken by the large number of teacher and student within a short time. By working hard for years, management information system for expert database has been established, by which we can randomly choose experts and realize anonymous review for projects and thus ensure fairness and impartiality.

\section{3) Management of Project Source}

Projects in HUC come from many aspects at present. Included is research project given on bases of school-running features of this specialty, research and innovation project needed by combing fine course construction with course teaching model reform, research subject announced by each center of practical teaching, project chosen by student individually and in groups in accordance with research expertise, social research project and the other valuable research and practice project, which can be managed by using information management system to avoid the content duplication and ensure innovation of newly applied projects.

4) Multi-direction choice of Student Leader, Project Member and Tutor

It is information management system that has realized multi-direction choice between instructor and student. That is to say, colleges firstly implement qualification examination for teacher and student, who have two-way choice on the bases of research project. In accordance with the result, teams of expert make the review and argument about projects. Finally, student leaders who have passed the interview set up teams of student's research. Student's leaders, project members and tutor make multi-direction choice and optimize team of research.

\section{B. Management of Project Process}

\section{1) Management of Proposal Presentation}

CNKI system of duplication checking has been used to check out proposal presentation for all the projects. Experts are organized to carry out anticipated instruction for every step of research project to correct some potential problems, to carry out detailed instruction for research process, project budget and work among members to change those projects which need replacing member, person-in-charge and instructor after discussion, which would ensure that project research continue smoothly. 


\section{2) Mid-term Examination}

In finishing half of research project, persons in charge can submit directly mid-term examination report, whose content includes difficulties, problems, project progress and the next work plan. Management department will organize mid-term examination and propose the improved suggestion. During the course of project, if personnel change, content and title alteration appear on account of different reasons, project leader will be required to fill in application and wait for approval fro m college and management department. Instructor and students who fail to finish the projects will be marked in intelligent management system and will not be permitted to apply the project within one year.

\section{3) Conclude the Project}

After finishing the project, team of project should fill in comprehensive research report of college students' innovative and entrepreneurial training program and attach the related material, research result and physical evidence, which will be examined by experts who management department organizes. When material and vital data provided by team of project is not true and complete or when team of project changes research objective and content without permission, these projects will not be accepted. Instructors and students will be marked in intelligent management system and cannot apply for any project of college students' innovative and entrepreneurial training program within two years.

\section{Informatization Management of Assistance, Monitoring and Supervision on Project Research}

\section{1) Assistance Function}

Through online training and lecture of related project provided by System, students can get corresponding helpful information according to what they want. System also provides link of lab opening platform and soften the terms in lab opening and input and output of experiment equipment, which will be beneficial to progress of project research.

\section{2) Monitoring Function}

On bases of project task book and in combination of project progress, system can carry out humanized message tone and thus guarantee project completion without missing anything. In the light of research content, scheduling and work among members, system can also urge members of project team to finish their own task on time.

\section{3) Supervision Function}

Members of project team can submit in management system the logbook, meet ing record in group, tutor's guidance and investigation material, against which management department can examine progress in research project, fund management and evaluate phrased result.

\section{4) Informatization Management of Project Funds}

Funds management adopts funds rendering process of "leader of project is in charge, tutor and leader of college checks and management department approves", namely, with leader of project filling out an expense report, leader can receive project funds at accounting department after instructor and leader of college examine and management department approves. During the period of this process, amount paid and ite m of expenditure will be written on line by leader of project. With instructor and leader of college checking on line and signing, students can download and print evidence for reimbursement according to number formed automatically by intelligent management system, which will simplify the process for reimbursement for instructor and students and implement real-time statistics to funds outlay and improve efficiency for management department.

\section{EFFECTS OF INFORMATIZATION MANAGEMENT}

\section{A. Increasing the Number of Projects, Fruitful}

As the first batch of approved project unit of college students' innovative and entrepreneurial training program in Heilongjiang province, Harbin University of Commerce has finally got 70 national-level and 20 provincial-level projects of college students' innovative and entrepreneurial training program from 2012 through 2013. Under the support of leaders, 247 school-level projects have been set up during the period, with each project given averagely $¥ 2000$ of project money. Project operation being good, 241 projects have passed final examination from colleges and HUC. More than 600 theses as research results have published at provincial and national periodicals, including 18 theses at national-level core periodicals. 22 patents and 210 entrepreneurial plan books have been accomplished respectively.

\section{B. Give Priority To the Cultivation of Students, Achieve the Dreams of Venture Company}

In In recent years, thanks to the joint efforts of the departments of school teaching practice management center, the Communist Youth League, school work and two grade school, the training program has focused on cultivating a number of typical projects.

Since 2012, the number of students participating in the practice of the entrepreneurship of college students has significantly increased, with a total of 86 people directly involved in the venture project practice, and 8 entity companies registered. The number of the students involved in work study programs and other forms of participation in the practice of the project has risen up to more than 400 .

Students' independent Venture Company: Blue Tide Information Technology Co. Ltd., Harbin Star Technology Co., Ltd. , Tatsu Service Co. Ltd.- services have been booming.

Blue Tide Information Technology Co. Ltd.: In 2012 the National College Students' innovation and entrepreneurship training program, project funding to support key projects; 2014 "A Youth Challenge Cup" National College entrepreneurship competition, entrepreneurship practice challenge bronze. The nature of the company: the company officially registered entities. After two years the basic mode of exploration and practice of the establishment of a commit ment, the members of the team explore creative marketing programs to raise the model of company. Currently it is the only one of the University's marketing services to promote the establishment of the public to raise public platform for Service Corporation. 
The company's core service platform name for the " Blue Tide dream factory", based on the domestic development boom in Internet banking industry, services for micro enterprises and small businesses, college students and excavation and collection, cohesion and enterprise products sales demand, to establish a complete product distribution chain. At the same time, the need of raising funds through the way to raise from the public of angel investor, spreading the risk and making creative glow. In the scope of radiation source of product sales will from domestic to imported products introduced, standardized purchasing industry, expand the export of the domestic products model, and ultimately the formation of product internationalization and international platform service system.

Harbin Star Technology Co. Ltd.: in 2013 2014, the National College Students' innovation and entrepreneurship training program, project funding to support key projects; 2014" A Youth Challenge Cup" National College entrepreneurship competition, entrepreneurship practice challenge bronze. The nature of the company: the company officially registered entities. Harbin Star Technology Co. Ltd.. was founded in January 2, 2014. The general manager of the company is 11 grade students at Harbin University of Commerce, Gao Yu. At the beginning of the venture, the first difficulty is that the problem is the capital and the field. But as an ordinary student, there is no money, but also how can there be a real office? To this end, the instructor Cheng Tao to his home as a place of registration, and for the company to invest 28500 yuan, so that the problem can be solved, Gao Yu was grateful. To solve the problem of the funds and place, Gao Yu took it for granted that the road will be s mooth sailing, but she did not expect is registered company need a series of complicated procedures, Do not want to give up. She kept constantly consulting, use both hard and soft tactics. Eventually, staff is touched by her dedication, with the exception for her quickly for the complicated procedures. The company has now reached a number of transactions. And Dell in Harbin District Commissioner made contact, held the Dell walked into the campus' notebook clinic 'activities, software development has and some counties of cooperation with the government, responsible for making its Web site.

Tatsu Service Co. Ltd.: In 2013 2012, the college students' innovation and entrepreneurship training, entrepreneurship practice project, the key support. The team based on the regional strong, the composition of the crowd characteristics, the relative stability of the district to carry out a more in-depth and comprehensive platform for cooperation. Such a platform of cooperation practice contain in general can be summed up as three main business: to promote the business to join the discount card; business value-added services outsourcing; business to suppliers, value-added partners, sales outsourcing to join our online and offline under marketing flat station. With the gradual development of the project, the gradual formation of the business district, the team has also been fully exercise, after a full test, so as to achieve their full development. And now the team has from the orig inal four core team over to by four as the core, two appointed by the senior management staff, five senior management personnel, nearly a hundred of the grass-roots staff system team. The internal management is graduates, in-service middle or bottom sales type talent, unemployed and laid-off workers (hereinafter referred to as "micro power"), by micro power creative marketing plan of

reasonable and orderly, the crisis management is fast and effective, and the executive ability is very strong. At present, already have investment in people, including high and new tech Development Zone, Harbin insiders, began on the project of our team and business research, and provide more effective support and guidance for us.

Yi Xia Tartary Buckwheat Series of Food Co. Ltd.: Harbin University of Commerce Communist Youth League "Challenge Cup a Youth Foundation," 2014 "A Youth Challenge Cup" National College entrepreneurship competition competition silver MBA special.Team members in under the guidance of tutor Professor Ma Xingsheng from Sichuan Liangshan $\mathrm{Yi}$ traditional buckwheat tea making method, fusion of modern food processing technology, the development of the new generation have the health benefits of natural instant tartary buckwheat tea series products. The company's goal is to create a business model for the establishment of the industry attributes on the hidden, competitors cannot imitate the long-term competitive advantage. With strong research and development strength to rely on, based on in Chinese traditional flavor drinks launched for the taste of the Chinese public nutrition, health, convenient and quick, spread the Chinese food culture, disseminating area dietetic habit. Team members in the process of participating in a large number of market research, a total of more than 1000 valid questionnaires. Through product analysis, company management planning, and finally the data collation of financial analysis, the completion of the business plan. In the final, team members and from the entrepreneurial team together to learn, discuss, share each other's dream of entrepreneurship and entrepreneurial experience, and constantly improve the business plan. In reply, the same day, calm in the face of the judges' questions, with an open mind to accept judges put forward suggestions, and ultimately achieve the MBA special competition silver. Team leader Cheng Jianbo talked about when we see the flag on the awarding ceremony was held, the name appeared on the big screen, our eyes moist!, we know a bit sad that we ever through at that moment is worth!

Jane Solid Technology Co. Ltd.: Harbin University of Commerce Communist Youth League "Challenge Cup - a youth foundation," 2014 "A Youth Challenge Cup" National College entrepreneurship competition business plan competition bronze award." Jane Solid Technology Co. Ltd." is a reform of the saline soil subgrade treatment of the business plan, and strive to the most scientific and effective way to solve the problem of land salinization. The team and the patent holder established the cooperative relationship, and achieved the transfer of patent licensing in the way of technology. In one year, the team went to the country more than ten times, determine the Dongying Shandong, Yantai, Panjin, Liaoning, Heilongjiang and Daqing, four typical cities as a product of the experimentation area. Made a lot of first-hand information. With the help of guidance teacher Zhang Jinsong, the team's success and our province listed Long Jian Road \& Bridge Co., 
Ltd Company signed a product trial contract. The contract lasted 9 months, members of the team accumulated 1100 hours of work, records engineering interview record more than 20 papers and complete entrepreneurial projects report page 137, in June this year, the successful completion of production test for two stage second grade highway, and according to the field application effect, Issued a product quality inspection certificate, product trial report, the enterprise operational entity. After the solid accumulation, the project won the gold medal, and successfully nominated in the tournament, won the national tournament bronze good results.

\section{Training effect}

Economics and management professional students' practical ability, innovation ability is enhanced, welcomed by employers, it has more advantage in the banking, finance, insurance, logistics, tourism and other fields.

Science and engineering students with certain management ability and innovation ability favored by the employers. With great influence in the domestic food industry, pharmaceutical industry, air conditioning industry, refrigeration industry, packaging industry, food machinery and packaging machinery industry, electronic commerce etc.

Nearly four years the employment rate remained at more than $96 \%$, the overall evaluation of employers to the graduates of our school satisfaction rate of $90 \%$. Heilongjiang authorities, the provincial tax authorities of business management financial management, financial sector $50 \%$ fro $m$ my school, the school has become the cradle of cultivating the high-level management personnel training.

\section{IV.CONCLUSION}

Development and practice of intelligent management system helps to supervise the entire project process, which ensures finishing project management in high quality and efficiency. Realize this kind of communication "humanized message tone" and finished the task in time. Log function has been used for the purpose of supervising progress in student's project. Distance evaluation from experts, such as online anonymous examination and online defense, has been turned into reality. Included is budget for project money, valid control for expenditure, automatic collection for results and query. All these things mentioned above can contribute to management and implementation of school- level, provincial-level and national-level projects in an order, scientific and high-efficient way, which has also done a useful exploration for innovating talent-trained model and establishing project management mechanism of innovative and entrepreneurial training program.

\section{REFERENCES}

[1]. Gao Yuan, College students' innovative entrepreneurial training plan of project process management research and exploration [J], Journal of laboratory science, 2013 (6),pp.71-74.

[2]. Yang Weizhi, Using the simulation system to cult ivate students ability of enterprise management [J], Journal of laboratory research and exploration, 2013, no. 4, pp. 11-13.

[3]. Zhang Li,Applied talents cultivation of innovative thinking mode exploration [J], China's higher education, 2012, (19), pp.12-13

[4]. Chen Yinping, Yin Long, College students' innovative entrepreneurial training plan to carry out the practice and exploration, in Harbin university of commerce, for example [J], Journal of new economy, 2014,(15), pp. 41-54.

[5]. Si Songmen, Zhuang Yale, Thinking about college students' innovative entrepreneurial training program [J], Journal of heilongiiang education (higher education research and evaluation), 2014, (7), pp. 31-33. 